\title{
Brazilian Nursing Association: fight for space in the new federal capital
}

\author{
Associação Brasileira de Enfermagem: luta por um espaço na nova capital federal \\ Asociación Brasileña de Enfermería: lucha por un espacio en la nueva capital federal
}

Kyvia Rayssa Bezerra Teixeira' ORCID: 0000-0003-1556-4178

Paulo Joaquim Pina Queirós" ORCID: 0000-0003-1817-612X

Maria da Graça Moreira Moscoso Marques"' ORCID: 0000-0001-5322-8672

Marcleyde Silva de Azevedo Abreu' ORCID: 0000-0002-4267-0550

Pacita Geovana Gama de Sousa Aperibense ${ }^{\text {IV }}$ ORCID: 0000-0002-3176-2134

Antonio José de Almeida Filho' ORCID: 0000-0002-2547-9906

Tânia Cristina Franco Santos' ORCID: 0000-0003-2325-4532

'Universidade Federal do Rio de Janeiro. Rio de Janeiro, Rio de Janeiro, Brazil. "Escola Superior de Enfermagem de Coimbra. Coimbra, Portugal. "'Universidade Federal Fluminense. Niterói, Rio de Janeiro, Brazil. "Universidade Federal do Rio de Janeiro. Macaé, Rio de Janeiro, Brazil.

How to cite this article: Teixeira KRB, Queirós PJP, Marques MGMM, Abreu MSA, Aperibense PGGS, Almeida Filho AJ, et al. Brazilian Nursing Association: fight for space in the new federal capital. Rev Bras Enferm. 2021;74(3):e20200701. https://doi.org/10.1590/0034-7167-2020-0701

Corresponding author: Kyvia Rayssa Bezerra Teixeira E-mail: kyvia_sax@hotmail.com

EDITOR IN CHIEF: Dulce Barbosa ASSOCIATE EDITOR: Álvaro Sousa

\section{ABSTRACT}

Objectives: to analyze the transfer process of the Brazilian Nursing Association to its new headquarters in Brasília/Federal District. Methods: qualitative, socio-historical, and documental study. The analysis generated the following characteristics: Associate reorganization: the transfer from the Central ABEn headquarters; and the Strategies used in the struggle for the appropriation of space. Results: the Brazilian Nursing Association was engaged in a struggle, which lasted nine years, for the acquisition of land in the new Federal Capital, Brasilia, to ensure a prestigious place for the Association, and for nursing as well. Final Considerations: together with their sections, undertook efforts and implemented strategies to find a space in the new Federal Capital, allowing visibility and recognition to the nursing profession. Descriptors: History of Nursing; Societies; Organizations; Brazil; Nursing.

\section{RESUMO}

Objetivos: analisar o processo de transferência da Associação Brasileira de Enfermagem para sua nova sede em Brasília/Distrito Federal. Métodos: estudo qualitativo, sócio-histórico, documental. A análise gerou as seguintes categorias: Reorganização associativa: movimento de transferência da sede da ABEn Central; e Estratégias utilizadas na luta pela apropriação de espaço. Resultados: a Associação Brasileira de Enfermagem esteve engajada em uma luta, a qual durou nove anos, pela aquisição de um terreno na nova capital federal, Brasília, no intuito de assegurar um lugar de prestígio para a Associação, bem como para enfermagem. Considerações Finais: a Associação Brasileira de Enfermagem, juntamente com as suas seções, empreendeu esforços e implementou estratégias para a ocupação de espaço na nova capital federal, possibilitando visibilidade e reconhecimento à profissão da enfermagem. Descritores: História da Enfermagem; Sociedades; Organizações; Brasil; Enfermagem.

\section{RESUMEN}

Objetivos: analizar el proceso de transferencia de la Asociación Brasileña de Enfermería a la nueva sede en Brasília/Distrito Federal. Métodos: estudio cualitativo, sociohistórico, documental. El análisis generó las siguientes categorías: Reorganización asociativa: movimiento de transferencia de la sede de la ABEn Central; y Estrategias utilizadas en la lucha por apropiación de espacio. Resultados: la Asociación Brasileña de Enfermería estuvo comprometida en una lucha, la cual duró nueve años, por la adquisición de un terreno en la nueva capital federal, Brasília, con el objetivo de asegurar un lugar de prestigio a la Asociación, así como a la enfermería. Consideraciones Finales: la Asociación Brasileña de Enfermería, juntamente con sus secciones, emprendió esfuerzos e implementó estrategias para la ocupación de espacio en la nueva capital federal, posibilitando visibilidad y reconocimiento a la profesión de enfermería.

Descriptores: Historia de la Enfermería; Sociedades; Organizaciones; Brasil; Enfermería. 


\section{INTRODUCTION}

The 1960s represented a time of important transformations in the Country's political-geographic scenario due to the transfer of the Federal Capital from Rio de Janeiro to the city of Brasília. Among other consequences for nursing, this event implied the transfer of the Brazilian Nursing Association (ABEn), with 34 years of existence and the only nursing representative entity at the time.

The Capital's transfer occurred on the symbolic date of April 21,1960 . It should be noted that the move to the middle of the country was already planned since the beginning of the Republic, as described in the Constitution of 1891. However, since it is a considerably expensive feat, only after decades of discussions, the Capital's transfer finally occurred under President Juscelino Kubitschek's administration ${ }^{(1)}$.

Other aspects related to the fact that the construction of the new Capital would bring the ideal of modernization of the Brazilian society. Economically, the justification consisted in the interest of increasing the economic frontiers aiming at the National capitalist expansion. All these factors made it difficult for the federal capital to remain in the city of Rio de Janeiro, thus confirming that the city was not qualified to continue to exercise this function ${ }^{(2)}$.

With the Capital's transfer, ABEn was forced to do the same because, according to its Statute, the Association headquarters should be located at Federal Capital. Therefore, before the country's political scenario, questions emerged related to the composition and demarcation of a space in the new capital, Brasilia.

ABEn, created by the former Ana Nery Nursing School students in 1926, was initially named as National Association of Registered Nurses - ANED (Associação Nacional de Enfermeiras Diplomadas). With time it passed through different modifications, changed its name to Brazilian Nursing Association (ABEn) in 1954, and had sections in several States, including Brasília, at the beginning of $1960^{(3-5)}$. With the creation of the sections, there was a need to differ the main Association/National Association, which was then referred to as Central ABEn, the reason it will be named hereinafter in this study.
Despite part of the Rio de Janeiro press treated the case as a "hearsay"(2), the change of capital happened, so the Association had to try to find a space to host the new headquarters.

\section{OBJECTIVES}

To analyze the transfer process of the Brazilian Nursing Association to its new headquarters in Brasília/Federal District.

\section{METHODS}

\section{Ethical Aspects}

The research was approved by Research and Ethics Committee complying with Resolution No.466/2012, of the National Health Council. As it is a study that uses only public and open-access documents, it is also supported by Resolution No. 510, of April 7,2016 , of the aforementioned council.

\section{Theoretical-methodological framework}

The present study is linked to the socio-historical process of symbolic struggles undertaken by nurses, and the data analysis is based on the concepts of "field," "capital," "power," and "symbolic struggle," developed by the French sociologist Pierre Bourdieu. Such concepts were useful to understanding nurses'symbolic capital, which granted the necessary symbolic power to them in the struggle for the appropriation of geographical and, at the same time, a social space, which was the construction of the new headquarters of the Association, a representative entity of the nursing field of that time.

\section{Type of study}

It is a qualitative, socio-historical study of the documentary type. The direct historical sources ${ }^{(6)}$ of the study included written documents: the ABEn Statute, presidents'reports, official letters, letters and communications, copies of the Brazilian Nursing Magazine of the 1960 s and 1970 s, and the ABEn documentary (1926-1976), produced by Anayde Correia de Carvalho. Documents are described in the following Chart 1.

Chart 1 - Direct sources that supported the research presented in chronological order, Brasília and Rio de Janeiro, Brazil, 1960-2008

\begin{tabular}{|c|l|l|l|l|}
\hline No & Year & Type of document & Description & Localization \\
\hline 1 & 1960 & Communication & $\begin{array}{l}\text { Communication sent by the president of Central ABEn to Dr. } \\
\text { Alfredo Ribeiro. }\end{array}$ & CEMEnf. Box 36. \\
\hline 2 & 1960 & Communication & $\begin{array}{l}\text { Communication sent by the president of Central ABEn to the } \\
\text { president of the Brasília section. }\end{array}$ & CEMEnf. Box 36. \\
\hline 3 & 1960 & Official Letter & $\begin{array}{l}\text { Communication sent by the president of Central ABEn to the } \\
\text { NOVACAP Director. }\end{array}$ & CEMEnf. Box 36. \\
\hline 4 & 1962 & Recommendations & $\begin{array}{l}\text { Recommendations of the General Meetings of the Central ABEn } \\
\text { of July 16, 17, and 21, 1962. }\end{array}$ & $\begin{array}{l}\text { REBEn, Rio de Janeiro, n. 4, year XV, p. 386-387, } \\
\text { Aug. 1962. CDOC EEAN/UFRJ. }\end{array}$ \\
\hline 5 & 1963 & Report & Legislation Commission Report (1962-1963) of Central ABEn & CEMEnf. Box 39. \\
\hline 6 & 1962 & Official Letter & $\begin{array}{l}\text { Official Letter sent by the president of Central ABEn to the Mayor } \\
\text { of Brasília. }\end{array}$ & CEMEnf. Box 41. \\
\hline 7 & 1963 & Balance Sheet & $\begin{array}{l}\text { Balance sheet sent by the 1 } \\
\text { president of Central ABEn. }\end{array}$ & CEMEnf. Box 40. \\
\hline
\end{tabular}




\begin{tabular}{|c|c|c|c|c|}
\hline No & Year & Type of document & Description & Localization \\
\hline 8 & 1964 & Report & Report by the president of Central ABEn (1963-1964). & CEMEnf. Box 40. \\
\hline 9 & 1964 & Official Letter & $\begin{array}{l}\text { Official Letter sent by NOVACAP Director to the president of } \\
\text { Central ABEn. }\end{array}$ & CEMEnf. Box 41. \\
\hline 10 & 1965 & $\begin{array}{l}\text { General Meeting } \\
\text { Recommendations }\end{array}$ & General Meeting Recommendations of Central ABEn, July 1965 & CDOC EEAN/UFRJ: Module AB. Box 04.1. \\
\hline 11 & 1965 & Newsletter & $\begin{array}{l}\text { Newsletter sent by the president of the Finance Committee of } \\
\text { Central ABEn to the president of Central ABEn }\end{array}$ & CEMEnf. Box 41. \\
\hline 12 & 1966 & Statute & Central ABEn Statute & $\begin{array}{l}\text { REBEn, Rio de Janeiro, n. } 5 \text { and 6, year XIX, p. } \\
\text { 641-651, Oct/Dec. 1966. CDOC EEAN/UFRJ. }\end{array}$ \\
\hline 13 & 1967 & Certificate & Certificate $1 / 67$ written by the president of Central ABEn & CEMEnf. Caixa 53. \\
\hline 14 & 1967 & Speech & Speech of the President of Central ABEn & $\begin{array}{l}\text { REBEn, Rio de Janeiro, n. 4, year XX, p. 213-217, } \\
\text { Aug. 1967. CDOC EEAN/UFRJ. }\end{array}$ \\
\hline 15 & 1968 & Communication & Communication sent by the construction office to Central ABEn & CEMEnf. Box 60. \\
\hline 16 & 1968 & Permit & Building permit & CEMEnf. Box 60. \\
\hline 17 & 1969 & Bulletin & July 1969 Bulletin - Central ABEn & CDOC EEAN/UFRJ: Module AB, Box 02.1. \\
\hline 18 & 1969 & Newsletter & $\begin{array}{l}\text { Newsletter sent by the President of the Special Commission for the } \\
\text { Construction of Headquarters to the president of Central ABEn. }\end{array}$ & CEMEnf. Box 60. \\
\hline 19 & 1969 & Newsletter & $\begin{array}{l}\text { Newsletter sent by the president of Central ABEn to the } \\
\text { presidents of the State Sections. }\end{array}$ & CDOC EEAN/UFRJ: Module AB, Box 02.1. \\
\hline 20 & 1969 & Report & Report by the president of the Central ABEn (1968-1969) & $\begin{array}{l}\text { REBEn, Rio de Janeiro, n. 4, } 5 \text { and 6, year XXII, p. } \\
\text { 235-249, Jul/Dec. 1969. CDOC EEAN/UFRJ. }\end{array}$ \\
\hline 21 & 1970 & Report & Report by the president of the Central ABEn (1969-1970) & $\begin{array}{l}\text { REBEn, Rio de Janeiro, n. 3, 4, 5, and 6, year XXIII, } \\
\text { p. 149-193, Jul/Dec. 1970. CDOC EEAN/UFRJ. }\end{array}$ \\
\hline 22 & 1971 & Report & Report by the president of the Central ABEn (1970-1971) & $\begin{array}{l}\text { REBEn, Rio de Janeiro, n. 5, year XXIV, p. 209- } \\
\text { 264, Jul/Sep. 1971. CDOC EEAN/UFRJ. }\end{array}$ \\
\hline 23 & 2008 & Documentary & ABEn Documentary 1926-1976 & EEAN/UFRJ Sector Library \\
\hline
\end{tabular}

Note: CEMEnf - Centro de Memória da Enfermagem Brasileira (Brazilian Nursing Memory Center); REBEn - Revista Brasileira de Enfermagem (Brazilian Nursing Magazine); CDOC - Centro de Documentação (Documentation Center).

\section{Study setting}

The sources were located in the Brazilian Nursing Memory Center (CEMEnf), in the National ABEn headquarters, in Brasília, and Documentation Center (CDOC) and Sector Library of the Nursing School Anna Nery/Federal University of Rio de Janeiro.

\section{Data source}

The production of data occurred from November 2017 to May 2019. The inclusion criteria were defined as following: written documents belonging to the time frame of the study, covering the period between 1960 and 1975, which contents included the strategies undertaken by ABEn in the process of transferring its headquarters to occupy the space. We used a guide for each document to subsidize its description and analysis though they were analyzed in a whole and not separately. Also, we considered the chronology of the events during the period of investigation.

\section{Collection and organization of data}

The selected sources were submitted to the process of external and internal criticism, i.e., a careful analysis aiming to determine the authenticity and the pertinence of the information contained ${ }^{(7-8)}$. We applied an adequacy analysis to select the sources and verify if it was in line with the study objectives. For that, this analysis included the aspects such as pertinence, aiming at the choice of documents adequate to the study objectives; sufficiency, through which the documentary corpus contemplated all sides of the problem; exhaustivity, not disregarding documents for reasons unrelated to the objectives of the study or analysis; representativity, making sure that the universe drawn from the documentary set represented the global universe; homogeneity, considering the similarity in the way to obtain data taken from sources using similar techniques; and organization of documents by sectors ${ }^{(9)}$.

\section{Analysis of data}

For the analysis of the documental corpus, we used the analysis of the context unit, considering social and symbolic structures that influenced the production of the speech contained in the source and that are, therefore, inherent to the process. We made this choice because, in this study, it is more important to explore the context in which a given unit occurred than just its frequency ${ }^{(10)}$. From the analysis of the findings, two categories 
emerged: Associate reorganization: transfer of the Central ABEn headquarters; and Strategies used in the struggle for the appropriation of space.

\section{RESULTS}

\section{Associate reorganization: transfer of the Central Associação Brasileira de Enfermagem headquarters}

The first movements regarding the transfer of Central ABEn headquarters to Brasília date back to 1957, when, in Deliberative Council from March 19 of the same year, the nurse Haydée Guanais Dourado addressed the subject, reminding the need to pledge to the competent authorities the donation of a piece of land in Brasília. However, the subject was not discussed at that time, according to the ABEn Documentary (1926-1976), in which Carvalho confirms that "the members present at that meeting were not prepared to listen to such proposal because the idea was not even discussed".

In the next year, the discussion about the transfer of the Federal Capital from the city of Rio de Janeiro to Brasília became more frequent. In this context, the nurse Haydée Guanais Dourado, who as the President of the Legislation Committee of Central ABEn at that time, was at the forefront of events to guarantee a good place for the Association and ensure representation of the profession in the new Federal Capital.

The first concrete action in this direction was carried out in 1958 by the then-president of Central ABEn, Maria Rosa de Souza Pinheiro. That same year, she received a letter from nurse Cacilda Rosa Bertoni, an associate from the Section of the State of Goiás, suggesting the acquisition of a land in Brasilia. This suggestion was also included in the report of the activities of the section, referred to the years of 1958 and 1959, in which they considered that the request should be carried out that time while its acquisition was facilitated.

After reflections and by the decision of the Central ABEn board, the president forwarded the official letter to the President of the Republic on August 6, 1958, requesting the donation of land for the construction of the new headquarters. In the next year, they organized a committee, whose president was the nurse Maria Geralda Franco, to deal specifically with the subject. When this committee contact the Urbanization Company director of the New Capital of Brazil (NOVACAP) in 1959, he noticed that the request had not yet been analyzed. Throughout this process, ABEn also relied on the assistance of its Legislation Committee and, later created a Special Committee to deal specifically with the subject.

The process involved several donation requests, which included the documents needed, in addition to the description of the properties that Central ABEn owned in Rio de Janeiro, which could be placed as a mortgage for land acquisition. The documents informed the Association's characteristics, emphasizing its public utility and its importance at the National level.

In June 1960, the president of Central ABEn, Marina de Andrade Resende, sent an official letter to NOVACAP director informing that, after the Brazilian Nursing Congress (CBEn) in that same year, some nurses would visit Brasilia requesting that, in the occasion of the visit, the public act of donation of the land was done. However, that did not happen at that time.
Later in 1960, the president of the Legislation Committee of Central ABEn informed through the committee report that she and the nurse Maria Jose de Abreu, who was in charge of monitoring the process in Brasília, visited the president's and director's office at NOVACAP, to hand again the documents necessary for the progress of the process. At that time, they were promised attention to the process at hand.

Maria Jose de Abreu was the person in charge of monitoring the process in NOVACAP to keep the Central Association board informed. She continued the follow-up in 1963, during the management of Clarice Ferrarini (1962-1964), and then passed the position to the nurse Haydée Guanais Dourado, who was in charge to receive the donation of the land and took all the responsibilities inherent to the possession of the power of attorney, by the president of Central ABEn.

The land donation was granted in December 1963, though the instrument of investiture remained in the process until 1967 when it was finally signed. In the official letter sent by the NOVACAP director to the president of Central ABEn, in 1964, was included the donation authorization of the land, and the request for "immediate appearance to finalize the donation process". It also included the term of 120 days for the conclusion of the process, "under penalty of expiration of the donation and its offer to other entities interested to invest in the Capital of the Republic." Despite political events delays the proceeding of the land donation process to the headquarters in the Federal District, the process was in the final stage, awaiting only the release for payment of taxes.

Thus, the slow progress of the process was not only due to the bureaucracy in internal processes in NOVACAP, since the Association itself had difficulties to follow-up the process, as informed by the president. Such difficulties culminated in six years, from the first request for the donation of land until the signature of the instrument of investiture occurring only in 1967, three years after the act of donation.

\section{Strategies used in the struggle for the appropriation of space}

In 1964, aiming to focus efforts for the headquarters construction, the Association constituted a Special Committee, under the presidency of Diva Câmera, a nurse who was a former treasurer at Central ABEn in the past. The "General Meetings Recommendations" of July 1965 suggests that the "Legislation Committee had headquarters in Brasília, and representation in Rio de Janeiro, or vice-versa." The document was based on the understanding that the country would have its administrative capital in two cities, Brasília and Rio de Janeiro, at that moment and for a few more years.

During the General Meeting that occurred in July 1965, the president of the Special Committee for Construction, nurse Diva Câmera, informed that had gotten an extension of three months to start the construction. This postponement was important because there was a threat of losing the land if the works were not started immediately. It is worth highlighting that, even with the pending ownership transfer process, the Association continued the measures that would advance the process until the donation was made official. Thus, at the beginning of 1965, Central ABEn provided the cost plan for the construction and measurement of 
the land, fencing of the area, and the production of floor plans to deliver to NOVACAP.

In parallel with these actions, the Central ABEn opened the Brasília's section on May 18, 1960, which was an important ally in this process. This union was fully evidenced when, in less than one month, the then-president of Central ABEn, Maria de Andrade Resende (1958-1962), sent a mail to the presidency with thanks, stating the importance of the collaboration of the newly created section to the Legislation Committee of the Central ABEn by being responsible for following the process No. 3.867, from December 11,1959 , which dealt with the request for the plot of land to build the future headquarters of the Association in Brasília.

The Federal District Section was very active. So much so that in 1962, two years after its creation, it forwarded recommendations to Central $A B E n$, which approved them in the same year in Assembly of Delegates held during the XIV ABEn. Recommendations were as follows:

1. That ABEn, in the name of the General Meeting, [wired] to Congressman Janduhy Carneiro, rapporteur of the amendment to Federal Government budget for 1963, requesting to endeavor to maintain the funding of $\mathrm{Cr} \$ 10,000,000,00$ for the construction of the headquarters in Brasilia, 2. That the sections work together with their Congressmen in the same direction. 3. That ABEn instituted the "brick campaign to build the headquarters."

The Federal District Section also promoted courses, scientific and social events, having hosted the XIX CBEn in 1967. On that occasion, the president of Central ABEn, Circe de Melo Ribeiro (1964-1968), explained the reasons for choosing the city for the event, emphasizing that it represented the confidence that the Association placed in the new capital project. Circe de Melo also mentioned that the construction of the Association's headquarters in Brasília was possible because NOVACAP met all the Brazilian nurses' requests.

The signature of permanent ownership of the land occurred in March 1967, nine years after the donation act. According to the Central ABEn newsletter of July 1969, the official donation of the land was complete on March 5, 1967, in the City Hall of the Federal District. The deed of donation was drawn at the First Notary Office in the presence of the president of NOVACAP, Israel Novaes, and the president of Central ABEn, Circe de Melo Ribeiro. From the date of the ownership of the land, a period of two years and two months has been established for the beginning and completion of the construction. However, there were again difficulties to meet the deadlines established due to the lack of financial resources.

Also, in 1967, the land deed was drawn after the approval of the third floor plan. On July 21 of that same year, during the Delegates Meeting, on the last day of the XIX CBEn in Brasilia, the cornerstone of the headquarters was laid. In that ceremony, held in the land of the new headquarters at Modulo B, Superquadra 603, Avenida L 2, N, the president of NOVACAP was present, representing the Mayor of Federal District and a large number of congresspeople.

Despite the regulation of the land donation in 1967, the construction has only begun in 1968, after several warnings informing the repossession of the land due to the delay of the beginning of the construction. The postponements happened because the commission needed to raise financial resources and adapt to the requirements for building the headquarters. However, such postponements also happened due to the delay in the project's approval by the Federal District City Hall. Such approval occurred on July 23,1968 , and the permit was granted on December 9 of the same year.

In the next year, 1969, Brasília Section was noted when the first-lady of the Country Scila Nogueira Medici, offered a teatime to the students and teachers of the Home Emergencies Course, sponsored by the section. This social event was also attended by the president of Central ABEn, Amália Corrêa de Carvalho.

In the end of 1969, when Central ABEn had new management, and Amália Corrêa de Carvalho as the president (1968-1972), the association faced again the threat of repossession of the land, due to the interruption of the construction. There were several attempts to regain possession because other associations started to be interested by the land, not only by its extension, but also by the location in the Grandes Areas Norte Sector, intended for institutions. Therefore, the president of Central ABEn together with Sister Maria Tereza Notarnicola, in order to guarantee the continuity of the ownership of the land, presented the activities that had been carried out by the Association, in favor of the progress of the construction, such as geological research and the preparation of the land for the water connection.

It is worth emphasizing that Sister Maria Tereza Notarnicola was the first treasurer of Central ABEn in charge of rendering accounts of the construction process of the new headquarters, working together with the Special Financial Committee. This committee was created in 1967 to focus efforts on building the headquarters, having Sister Catarina Colavite from the Congregation Sisters of Charity as president, although she spent little time in charge of the commission for being transferred from the Federal District, requesting resignation from office.

Trying to solve the situation, Sister Maria Tereza Notarnicola was called to help the nurses from Brasília while she organized a new committee. This new committee was formed in a meeting of the Association, held on July 22, 1967, to discuss the headquarters' construction. The nurses nominated was Alice Andrade Maciel, presidency; Diva Câmera, as treasurer; and Maria das Graças Negromonte, Maria de Lourdes Cunha, and Margarida M. Pequeno Fernandes as associates. The declaration written by the president of Central ABEn in 1967 included that the commission was granted "full powers to authorize the start of construction, sign documents and deal with any and all matters relating to the headquarters' construction."The president of the committee, Alice Maciel, informed the president of Central ABEn, through an official letter, that the repossession of the land did not happen due to the nursing influence over the Deliberative Council of NOVACAP. In total, between 1967 and 1969, Central ABEn faced three attempts to retake possession by NOVACAP.

The committee was congratulated by president Amália Corrêa de Carvalho (1968-1972) in her 1969 report. She informed that the construction was in the final stage thanks to the dedication of the Headquarters Special Committee (located in Federal District), especially Alice Andrade Maciel and Diva Câmera, president, and treasurer respectively, and the liberality of nurses through the Sections to which they belonged. 
After those years of intense struggles and changes, the opening ceremony of the first part of the project finally took place, as part of the celebrations of the $32^{\text {nd }}$ Nursing Week, on the $15^{\text {th }}$ of May of 1971. At that time, two nameplates were set, one institutional and another individual, with the names of the persons and institutions that contributed to the completion of the building, in recognition for their help. Some people received the Award of Merit for having contributed monetarily or with service for the construction and with the sections that went beyond the established goals. Civil, military, and religious authorities were present at the ceremony, and also members of the Central ABEn board of directors, from Brasilia Section, and representative members from almost all State Sections.

They intensively struggle for 13 years in this process of transferring the headquarters. During this long time, that lasted from 1958 to 1971 , the Association has gone through five administrations, with the following presidents: Maria Rosa Souza Pinheiro (1954-1958), Marina de Andrade Resende (1958-1962), Clarice Ferrarini (1962-1964), Circe de Melo Ribeiro (1964-1968), and Amália Corrêa de Carvalho (1968-1972).

The nurse Amália Corrêa de Carvalho took office in 1972, for the management of 1972 to 1974, and was in charge of finishing urbanization and landscaping for the external area and constructing the rainwater gallery. Her successor, Maria da Graça Simões Côrte Imperial (1974-1976) was in charge to finish the construction, ornament, and definite establishment of the headquarters, and, for the implementation of these two last items, the president counted on the work of the executive secretary, Clarice Ferrarini.

In 1974, the final arrangements for the definitive change of the headquarters were under the responsibility of Sister Maria Tereza Notarnicola, nominated by the Central ABEn board of directors. As shown in ABEn Documentary (1926-1976), this movement occurred because the headquarters was legally already in Brasília for the following reasons:

1) by the amendment in Article 1 of the 1973 Statute; 2) by the cancelation of the registers at ABEn in Rio de Janeiro and new registers in Brasília and 3) by publications of the change in the Federal and State Official Gazettes.

The amendment concerned article 1, paragraph 1 , of the statute, which previously described: "ABEn has, for an indefinite period, provisionally, the headquarters and venue in the city of Rio de Janeiro, GB" (ABEn, 1966, p. 641). The modifications were published in the Official Gazette (D.O.) of the Federal District, on September 9, 1973, and in the State Official Gazette, on December 10, 1973. Finally, in 1975, the Central ABEn administration settled definitively in Brasilia.

The sections were an essential part of this movement. In the 1963 balance sheet, even before the creation of the Special Committee for the Construction of the Headquarters, which facilitated the action between sections, there was already a description of thanks to the sections that had already been mobilizing to assist the Association in raising funds. The document included special thanks to the Section of the State of Sergipe, which was the first to contribute with the "Brick Campaign".

In 1964, Sister Tereza Notarnicola, president of the Financial Committee, after authorization to grant land, wrote a letter to the president of Central ABEn informing that they would use all the available resources and count on the Section's help since ABEn had no other means of subsistence than its sections.

As a way to raise more funds for the construction process, the nurse Haydée Guanais Dourado proposed a general plan in 1968, which included the sections' division into groups that would be responsible for making donations in favor of the Central $A B E n$ headquarters, according to the number of associates of the section and region in which they were settled, since the number of nurses by region was variable as well as their salaries.

The presidents' management reports indicated several suggestions and proposals presented by the sections for execution. Among them were the Brick Campaign, raffles, bazaars, subventions by the Congresspeople, members recruitment campaign, individual donations by nurses, individuals or institutions related to nursing, parties, campaigns in nursing and nursing assistant schools, elaboration of a gold book through which donations would be made to a construction fund, solicitation of donations to federal nurses, who were possibly the ones who received better salaries and, therefore, presented a greater possibility of donation, promotion of courses to update nurses and nursing assistants, and a course on Nursing Home. Such strategies were initiated in 1958 and lasted until the completion of the building.

Regarding the difficulties faced during the process and the actions implemented by the sections, the president of Central ABEn, Amália Corrêa de Carvalho (1968-1972), registered in her report (1968-1969) the unique experiences of the work carried out in that period. She also mentioned that the significant financial issues experienced made it possible to assess the degree of unity of the class through the State Sections, which demonstrated a spirit of collaboration worthy of the highest praise in the face of that scenario, and only because this unity it was possible to continue the project. For this reason, she reported that she felt deeply thankful.

The investment in this process required significant donations of financial inputs and workforce, and the help of the sections was fundamental. The financial aspect hindered other important activities at $A B E n$, such as the proximity between the central administration and the sections themselves, as the president Amália Corrêa de Carvalho (1968-1972) described in her report, confirming that it became impossible to allocate any financial resources to other activities due to the onerous financial obligations related to the construction of the new headquarters.

The president of Central ABEn, Amália Corrêa de Carvalho, registered this feeling in a report corresponding to the period from September 1969 to June 1970. In this report she alleged that the construction process of the new headquarters confirmed the unity among the associates, and also the visibility of a small group of women, in favor of a strong and valid ideal, i.e., the construction of a heritage of inestimable social and cultural value for Brazilian nursing, which would be enshrined in the chapter destined to narrate the important achievements of the association.

\section{DISCUSSION}

For nine years, the Brazilian Nursing Association was involved in a symbolic struggle ${ }^{(11)}$ regarding the transfer process from the headquarters to Brasilia both because of the need to comply with the statute and because of the understanding of the symbolic 
profits arising from the occupation of space for institutions in the new Federal Capital. Thus, it undertook strategies for the acquisition of the land and construction of the headquarters in the space. To be successful, it made use of the symbolic capital raised by the association and its leaders, especially through the field of nursing education. This is because "the capital is the energy that drives the development of a field over time"(12). In this regard, the Association, as a space for social production and distribution of these symbolic capitals, undertook strategies to use this capital as a symbolic instrument in the struggle for the acquisition of the land.

These strategies included the creation of special committees with prestigious nurses, who occupied positions of power in nursing schools or in ABEn itself, these being the credentials that gave visibility to the group's expertise and, consequently, its professional and social recognition ${ }^{(13-14)}$, several meetings in Brasília with government representatives, creation of new headquarters in Brasília, while important support to nurses coming from Rio de Janeiro was constituted at the same time, it also gave visibility, through the creation of another state section, and prestige to the Association.

It should be remembered that the transfer process was long and, thus, the Association kept most of its administration in Rio de Janeiro. To take the appropriate steps to change the location of the headquarters, the trips made by the president of the Legislation Committee, Haydée Guanais Dourado, were essential both for the aspect of pending solutions and for the symbolic effect of the presence of a prestigious person of Brazilian nursing in the affairs of the entity and the profession.

The creation of a Special Committee by Central ABEn was an important strategy to follow-up the transfer process, facilitating the Legislation Committee performance regarding the possibility to meet the Brazilian nursing requirements, with the same importance to the development of the professional. We understand that the creation of this Committee to address issues concerning the construction of the headquarters had been the most appropriate solution at that moment, instead of maintaining two legislation committee headquarters.

Also, the creation of ABEn Section in Brasília, was a significant step both to confirm the unity of the association and, as previously mentioned, to give it visibility because the capital is the place where budgets are approved and, being away from the capital means being away from the funds ${ }^{(15)}$. With the creation of the section, it was also possible to observe the Central ABEn concern in approaching local nurses, aiming to make them participate in the associations, and be aware of the nursing debates, and bring other issues of their profession arising from the services in which they worked as well, strengthening the union and the performance of nursing through its main organizational entity at the time.

The Brazilian Nursing Association - Brasília Section - had great prestige because its leaders could make claims directly to influential people in the political field. The volume and weight of their social and symbolic capital, certainly added to those of the associations, gave them a legitimate discourse and, therefore, a symbolic authorization to exercise such claim $^{(16)}$. Also, the presence of influential people in the ceremonies held by ABEn, for example, the first lady of the country, confirmed the recognition given to the nurses of this section, adding more symbolic capital to the Brasília Section to the Central ABEn as well.
The recommendations of the Brasília Section, and also their actions, highlight the engagement of nurses from this association in favor of their development, in a period marked by the struggle of Central ABEn for an important physical space in the capital of the country, which represent a social space as well. This is because the capital is "the place where the buildings of main knowledge fields are concentrated along with the most of their agents that occupy dominant positions ${ }^{(15) "}$.

The courses given not only by the Brasília Section but also by most sections of the Association in that period, which were encouraged by the board of ABEn Central, and which were part of the strategies to raise financial resources in favor of the construction of the new headquarters, also represented a possibility of bringing knowledge to the population, and to nurses and other nursing professionals as well. Thus, the professional associations offer a perspective of change, as they are configured in spaces that favor professional improvement and can also provide critical reflective training and an understanding of the political, social and professional context in which they are inserted ${ }^{(17-19)}$.

The donation process was long and challenging because Central $A B E n$ could not always count on the regularity of the transfer of financial resources since the State associations had their separate expenses, despite they were essential for the implementation of the headquarters transfer project.

The presidents of Central ABEn exalted and thanked the support given by the State Sections throughout the process in acquiring a space for the new headquarters. Such recognition was valuable for the State Sections because the presidents are authorized spokespersons for the group and, as such, can speak for other agents because their speech concentrates the symbolic capital accumulated by the group that gave them the mandate, and despite the difficult decisions required in that period, the symbolic value of the project in question exceeded the sacrifices ${ }^{(20)}$. Thus, such strategies, in addition to arranging for the construction of the association building in a prime area of the new capital, also granted visibility to the associations' work because the nurses engagement, represented by their associations, constitutes a relevant symbolic capital to be seen and recognized.

\section{Study limitations}

As study limitation, since the authors write from a social place, they are certainly influenced by questions of the now, therefore, the historiographic work suffer multiple influences, which are related to the social spaces that they occupy and are updated with time.

\section{Contributions to the fields of Nursing, Health or Public Policy}

The increase of numbers of researches on this subject may contribute to greater attention of nurses to the political aspects of the profession and can lead professionals to the construction of a united project with social commitment.

\section{FINAL CONSIDERATIONS}

The 17 years between the terrain solicitation (1958) and the implementation of the project (1975) confirm relevant perseverance 
and union among the Association nurses, who were crucial to achieving the consolidation of such an achievement.

Many strategies were needed to develop the project. In this matter, the State sections, mainly the Brasília's, were essential for the transfer of the headquarters to the capital. The engagement and articulation of the sections took place in a Country of continental dimensions, i.e., they could overcome the difficulties in terms of displacement between the two cities (Rio de Janeiro and Brasília), where ABEn's administration matters were located during the transition period to the Capital. In this sense, the creation of a new section in Brasilia and the help from the sections that already existed constituted the fundamental tool for the success of this project, which would represent an invaluable gain not only for ABEn, but also for Brazilian nursing.
The completion of donation and the transfer of ABEn's headquarters to Brasília symbolize the occupation of the Brazilian nursing space in the place where political games take place, where important decisions about the Country's directions are made, and Brazilian nursing is integrated thanks to the nurses efforts who were conscious about the important role in the fights for nursing.

Therefore, ABEn, as the first nursing organizational entity, played a leading role in the history of the profession. Such leadership is expressed in its existence, which has always been focused on the development of education and science in nursing. Thus, the association has always been present, in the symbolic struggles for visibility and professional recognition, with important political and social participation.

\section{REFERENCES}

1. Fausto B. História Concisa do Brasil. São Paulo: EDUSP, 2015. 688 p.

2. Motta MS. Rio, cidade-capital. Rio de Janeiro: Jorge Zahar. Ed., 2004. 71 p.

3. Teixeira KRB, Queirós PJP, Pereira LA, Peres MAA, Almeida Filho AJ, Santos TCF. Associative organization of nursing: struggles for the social recognition of the profession (1943-1946). Rev Bras Enferm. 2017;70(5):1075-82. https://doi.org/10.1590/0034-7167-2017-0186

4. Silva JL, Machado DM. Enfermagem brasileira em 90 anos de história associativa: contribuições da Associação Brasileira de Enfermagem. HereHist Enferm Rev Eletrôn [Internet]. 2018 [cited 2019 Nov 10];9(2):131-40. Available from: http://here.abennacional.org.br/here/v9/n2/a4.pdf

5. Germano RM. Organização da enfermagem brasileira. Enferm Foco. 2010;1(1):14-7. https://doi.org/10.21675/2357-7007X.2010.v1.n1.3

6. Barros JD. Fontes Históricas: revisitando alguns aspectos primordiais para a Pesquisa Histórica. Mouseion. 2012;12:129-159. https://doi. org $/ 10.18316 / 332$

7. Padilha MI, Bellaguarda MLR, Nelson S, Maia ARC, Costa R. The use of sources in historical research. Texto Contexto Enferm. 2017;26(4):e2760017. https://doi.org/10.1590/0104-07072017002760017

8. Abreu MSA, Haddad VCN, Costa LMC, Teixeira KRB, Peres MAA, Santos TCF. First officer nurses of the military police of the state of Rio de Janeiro (1994-1995): incorporation of military habitus. Esc Anna Nery. 2015;19(4):535-541. https://doi.org/10.5935/1414-8145.20150071

9. Barros JD. A fonte histórica e seu lugar de produção. Cad Pesqui Cdhis. 2012;5(2):407-29. https://doi.org/10.14393/cdhis.v25i2.15209

10. Cardoso FC, Vainfas R. Domínios da história: ensaios de teoria e metodologia. Rio de Janeiro: Campus, 1997. 693p.

11. Souza DF, Silvino ZR. A Sociologia de Pierre Bourdieu: potencialidade teórica para o subcampo da enfermagem. Rev Bras Enferm. 2018;71(4):2055-9. https://doi.org/10.1590/0034-7167-2016-0505

12. Grenfell M. Pierre Bourdieu: conceitos fundamentais. Petrópolis (RJ): Vozes, 2018. 400 p.

13. Aperibense PGG, Silva CPG, Santos TCF, Almeida Filho AJ, Nelson S, Peres MAA. The uniform of nursing students: a strategy for the construction of professional identity (1950-1960). Texto Contexto Enferm. 2019;28:e20170593. https://doi.org/10.1590/1980-265x-tce-2017-0593

14. Bellaguarda MLR, Padilha MI, Peres MAA, Paim L. The nursing profession: its status: that is the question. Rev Enferm UERJ. 2016;24(2):e8591. https://doi.org/10.12957/reuerj.2016.8591

15. Bourdieu P. Espaço físico, espaço social e espaço físico apropriado. Estud Av. 2013;27(79):133-44. https://doi.org/10.1590/ S0103-40142013000300010

16. Silva TF, David HMSL, Koopmans FF, Dahe DV. Construindo possibilidades em Bourdieu para análise do campo da enfermagem. Enferm Foco. 2018;9(1):49-53. https://doi.org/10.21675/2357-707X.2018.v9.n1.1384

17. Laitano ADC, Silva GTR, Almeida DB, Padilha MI, Peres MAA, Santos VPFA. Militancy of nurses in the institutionality field: printed media versions. Rev Bras Enferm. 2020;73(4):e20180835. https://doi.org/10.1590/0034-7167-2018-0835

18. Castro AR, Nobrega-Therrien SM, Almeida MI, Vieira DVF, Montesuma FG. Análise da trajetória da Associação Brasileira de Enfermagem: Seção Ceará. Rev Rene [Internet]. 2017[cited 2020 Jun 12];18(3):321-8. Available from: https://www.redalyc.org/articulo.oa?id=324053754006

19. Santos TM, Silva BT, Miranda JS, Guimarães JCS, Aparibense PGGS, Peres MAA. Contribuições da Associação Brasileira de Enfermagem para a Enfermagem Psiquiátrica: um olhar sobre os Congressos Brasileiros de Enfermagem (1947- 1981). Here-Hist Enferm Rev Eletron [Internet] 2016. [cited 2020 Jun 10];7(2):406-22. Available from: http://here.abennacional.org.br/here/2a04.pdf

20. Girardi Jr. L. Pierre Bourdieu: mercados linguísticos e poder simbólico. Rev FAMECOS [Internet] 2017. [cited 2019 May 21];24(3):1-14. Available from: https://www.redalyc.org/articulo.oa?id=495553932018 